\title{
A Theoretical Analysis of the Gezi Resistance: Implications for Political Communication of New Social Movements
}

\author{
Mine Yetkin, Anadolu University, Turkey \\ Ali Simsek, Anadolu University, Turkey
}

\begin{abstract}
On 28 May 2013 a peaceful demonstration by environmental activists who were protesting against the demolition of Gezi Park - one of the few green areas left at the heart of Istanbuland construction of a shopping mall along with a mosque instead was suppressed by excessive and aggressive police intervention. In response to the police suppression, thousands of individuals in Istanbul gathered in Taksim and Kadıköy followed by other big city centers in Turkey, which subsequently evolved into a resistance movement throughout the country. Particularly the peak days of the uprisings generated so much interests both in domestic and international public opinions, it was even perceived as the biggest political resistance in the history of modern Turkey. Although the government side tried to portray the incidents as "demonstrations" to degrade its impact, the opposition side presented the incidents as "riots" to boost participation. This paper aims to look from three years back at the Gezi Resistance in terms of its nature and grass-roots mobilization of masses and where it stands from the perspective of the New Social Movements Theory. Comparisons are made with similar social movements in other countries and implications for political communication of such movements are discussed.
\end{abstract}

Keywords: Gezi Park resistance, New Social Movements, Social Dissent, Political Communication 


\section{Introduction}

The main argument of this paper revolves around the assumption that the current New Social Movements that have been taking place since the early 2000s differ from the previous New Social Movements such as feminist movements, minority movements, ethnic and cultural movements. The main difference of these movements lies in their objectives and agendas: The previous New Social Movements were mobilized by particularized interest groups such as environmentalist movements or abortion rights movements. These movements were issuespecific and mutually exclusive in terms of participation. However the new social movements of the post 2000s encompass diverse interest groups that gather to form web of ties. Generally, the main issue that the diverse groups gather against is the globalization of capital, the neo-liberal economy and adverse impacts of globalization. It can be suggested that the common denominator of these participant groups that they are excluded members of the society from the current socio-economic order who are severely affected by the economic restructuration processes. Furthermore the previous forms of new social movements were mostly regional; however, the new social movements of the past few decades are global movements. That is to say, through networks and communication technologies, participants of the new social movements interact and influence one another throughout the world. This is seen from the similar repertoire and organizational structure of the movements.

Within this framework, the present paper analyzes the Gezi Park Resistance in a comparative fashion from a theoretical perspective. When the actors, dynamics and modes of activisms are considered, the Gezi Park Resistance show resemblance with other resistance movements happened in USA, Egypt, Spain, Ukraine etc. Subsequently the main question revolves around the issue of whether there is a transformation of the new social movements since the late 1990s in terms of values, issues, actors, repertoireand structure. Thus, a theoretical analysis New Social Movements as bourgeoning resistive and reactionary movements against the outcomes of the neo-liberal policies is crucial for unraveling the dynamics of the Gezi Resistance. The course of the argument is as follows: First, the nature, dynamics and actors of new social movements with regard to neoliberal order and globalization will be elaborated. Following this, the Gezi Park Resistance will be analyzed within this framework in a comparative perspective. Finally, implications of the Gezi Park Resistance for political communication of New Social Movements will be highlighted. Before continuing the 
theoretical discussion on New Social Movements, it would be helpful to briefly explain what happened on the $28^{\text {th }}$ of May 2013.

On 28 May 2013 entered the construction machines to raze Gezi Park- located at the heart of Istanbul it is one of the few remaining green areas open to public- and to build a shopping site and a mosque as part of the neoliberal gentrification projects. Against the demolition, a small group of environmental activists occupied the area starting a peaceful action. Police attacks with tear gas and water cannons to the peaceful group and finally setting their tents to fire at the dawn of $30^{\text {th }}$ of May, triggered the 20 days long massive protest and initiated a chain of protest movements countrywide.

The high level of police brutality, as the reflection and resemblance of the ruling Justice and Development Party (Adalet ve Kalkınma Partisi - AKP) authoritarianism, instead of intimidating the people increased the number of activists and their determination. After a certain point, the issue was no longer the local demand for Gezi Park but it was more about the oppressive and authoritarian AKP policies and politicians' discourse affecting every aspect of social and individual lives in general. By Gezi Park resistance, it is referred to the nationwide chain of protests, spontaneously formed by a wide variety of social groups with different problems and varying agendas, which held a long list of grievances against the government. The uniqueness and importance of the Gezi Resistance in Turkey's recent history lies in the fact that, it was the first time that a social movement encompassed a massive group of activists from different and conflicting ideologies, different identities and with different agendas. Therefore, the Gezi Resistance resembled the gathering of differences in Turkey that are collaborating and struggling in solidarity against the police brutality. The public celebrated this peculiarity of the Resistance with the expression of "Gezi Spirit" which has become a symbol of encounter and collaboration with the others in solidarity, whenever such solidarity is needed in the society.

Mirroring Gezi Resistance with other "occupy" and "take the streets" movements throughout the world, it would be helpful to analyze the phenomena in light of the New Social Movements paradigm. 
The new form of capital accumulation regime namely neo-liberalism and the transformations in the mode of production resulted in the commercialization of all areas of life, emphasis on symbolic production rather than material production, emphasis on individualization and transience. The neo-liberal dynamics are crystallized with privatization of public assets, high security, laws that concentrate power and promote neoliberal institutions, use of justice system to suppress and discourage dissent from authoritarianism, huge gap between the social economic strata disappearance of social welfare. The governments, while opening their doors to neo-liberal economies and to the necessities of foreign investments, couldn't achieve political transformation. This led people to suffer poverty and authoritarian rules.As will be seen in the following discussions, the dissent to the neo-liberal economy in the form of social welfare cuts and commodification as in USA and Spain or dissent to authoritarianism as in Arab countries, Ukraine and Gezi Park Resistance all suppressed by strong police forces.

Evaluating Gezi resistance within this theoretical framework, the construction of a commercial building as a part of urban transformation project at the heart of Taksim Square, other commercial transformations at the historical and natural urban settings of Istanbul and a chain of gentrification projects for significant neighborhoods involve a hegemonic struggle over the urban public spaces. The new middle classes started to raise their voice and claim rights over the urban areas that they inhibit as the urban transformation projects became a tool for government to determine and impose a certain lifestyle over people (Palczewsky, 2001: 204; Coşkun, 2007: 135; Kurtuluş, 2014: 274).

\section{New Social Movements: Theories and Actors}

For analyzing and providing a theoretical background to Gezi Resistance, theoretical approaches to the New Social Movements will be summarized, with reference to the literature, the contemporary social movements, their actors, the identity belongings of these actors and their post-materialist concerns will be discussed under this section.

Within the framework of post-industrialist, post-capitalist paradigm the discourses that take working class as the sole and central unit in explaining social movements and social struggles have been losing their validity. However, it is also important to mention that, as long as the mode of production that is based on private property and profit based exploitation continues the notion of "class" will exist. 
The fragmentation of classes in the post-industrial societies as well as inherent diversification of class (Public service workers, undocumented workers, organized workers, sub-class workers) complicates the development of a common class-consciousness. This case of the current class structure as reflected in the anti-systemic movements, the conventional working class with its revolutionary objective is replaced on the streets and squares by diverse groups that are organized around various identities and ideologies.

The New Social Movements paradigm flourished in Europe as a criticism to Marxism. The "newness" of the social movements lies in its formation around struggle for culture and identity politics. The participants of these movements do not struggle for material ends and/or seizing state hegemony, instead their main struggle is to be accepted with their own identities and life styles. Scrutinizing the peculiarities of the new social movements, Melucci (1996: 102-103) emphasize the diversified objectives and the weakness of the bargaining power of these movements. Additionally the new social movements have their peculiarity as they do not claiming control over power mechanisms within the political system, they challenge the private/public distinction with the famous feminist chant "personal is political", are particularistic, emphasize solidarity and direct participation (Melucci, 1996: 102-103). According to Cohen new social movements are different from their previous counterparts by their approach towards cultural and individual identities, advocating civil society against the technologic state, democratic decision making process, adopting democratic and participatory styles (Coşkun, 2007: 53-61). As will be discussed further, the new social movements after the 1990s have lost their emphasis on culture and identity but focus on inequality, deteriorating living conditions, exploitation and economic austerity as well as increasing authoritarianism.

New social movements are defined as the reaction of the professional middle class against the states' and market's colonizing power over the everyday life (Carty, 2011). In another definition of Offe (1985: 828) they are "those movements that do make a claim to be recognized as political actors by the wider community... and who aim at objectives, the achievements of which would have binding effects for society as a whole rather than just for the group itself". They are the movements that the "fusion of political and nonpolitical spheres of social life" is observed and where the dividing line between the political from private is blurred (Offe, 1985: 817). Furthermore, the denial for all kinds of representation by 
official political parties and conventional institutionalized civil society organizations is explained by Offe as follows:

"The politics of new social movements, seeks to politicize the institutions of civil society in ways that are not constrained by the channels of representative-bureaucratic political institutions, and thereby to reconstitute a civil society that is no longer dependent upon ever more regulation, control and intervention." (Offe, 1985: 820).

Clearly speaking, our daily life is under bureaucratic and technologic domination by states' intelligence and surveillance mechanisms additionally market opens every aspect of individual and daily space to consumption (Crossley, 2002). In that case new social movements can be stated as the resistance of the new middle class of different identities against the rising intervention of the state and the market and commodification of the social life as well.

Offe (1985: 820) while comparing the new social movements from its "old" counterparts, he focuses on its four principal components, namely the issues, values, actors and institutional practices. For the purpose of the discussion Offe's analysis will be utilized for evaluating Gezi Park Resistance and how it is situated within the broader context of geopolitical landscape of the contemporary new social movements.

According to Offe (1985: 828) the main issue of the new social movements involves "the concern with physical territory" that he defines as "space of action, or life world". The problems that are raised in the new social movements as Offe (1985: 829) mentions include any physical environment as the city, the neighborhood; cultural heritage and identity; and physical conditions of life as in the case of environmental issues. As will be seen in the further discussions the Gezi Park Resistance that started as a resistance for the preservation of a significant green space became a part of a larger issue of claiming right to the city, demanding respect for difference and challenging authoritarianism.

As for the values, according to Offe $(1985,829)$, the "most prominent ones are autonomy and identity" the represented in their decentralized, self-governed and self-help organizational structure. 
The third component of the new social movements is the mode of action. Offe (1985: 829), divides the mode of action into two aspects: the action of individuals towards forming a collectivity and their actions in confronting the political opponents. In the first one, multitude of individuals form a collectivity informally, ad hoc basis that is context dependent and discontinuous and egalitarian-leaderless-. The collectivity pertains a form of solidarity that depends upon voluntarism, networks and campaigns. In confronting the opponents, the protest tactics "are intended to mobilize public attention by unconventional means...the single veto alliance" that leaves room for variety of "legitimations and beliefs." (Offe, 1985: 830). As will be argued thoroughly in the following discussions, the participants of the new social movements mobilize different forms of passive/peaceful resistance tactics, sit ins, occupy movements, slogans and graffitis, vivid examples of them are frequently observed during the course of the movements. The multitude of actors with many "yeses" form a collectivity under "one no" in confronting their opponents.

To further the argument by introducing a categorical analysis of the key actors of the contemporary new social movements it could be referred to the notion of Multitude introduced by Hardt and Negri (2004). "Multitude is composed of potentially all diverse figures of social production and is based on the assumption that there is no priority among the modes of labor" (Hardt \& Negri, 2004). The notion of Multitude describes the common action composed of fragmented identities, encompasses all labor under the rule of the capital. The workers who produce the non-material labor, industrial workers, agricultural workers, the unemployed, the migrants and so on introduce heterogeneous structures gather under multitude (Hardt \& Negri, 2004: 175). Offe (1985: 831), explains this "multitudeness" of actors by the notion of self-identification. As these new actors don't identify themselves with conventional political codes of left/right or socio-economic codes of class conditions. Rather, the self-identification of the new social movements is based on the movements' issues. In that sense the new social movements do not involve a form of class consciousness despite the fact that they are predominantly formed by new middle class -a heterogeneous group that is defined according to their mode of consumption and life-style rather than their relation to the means of production-. As Offe (1985: 833) elaborates the phenomena by distinguishing the notion of "class awareness" from class consciousness. As in the former one the agents of the movement are determined as it is clear that who support the causes. However, the demands are not class specific so the demands are not on behalf of the class (Offe, 1985: 833). 
Therefore, Orthodox class categories fall short in conceptualizing the class positions of the actors of Gezi Park Resistance. For that purpose it would be useful to introduce the notion of the Prekariat Class that define the fragmentation within the middle class and its proleteriazation. The new working conditions and wage systems, technological developments resulted in the emergence of different wage worker categories other than working class (Coşkun, 2007: 16). The inherent fragmentation of the New Middle Class range from high level managers who attain power and control over symbolic capital such as information and technology to the wage workers who do not define themselves as workers but as for living conditions, income and devalued labor they obtain a similar position with the workers. Hence the New Middle Class can be described as "a compound containing all forms of labor exploitation that is outside of the industrial workers and for that reason, consolidating the inherent difference only with demands for economic, democratic and urban rights" (Kurtuluş, 2014: 266-267).

The notion of Precariat Class is functional in explaining this fragmentation inherent in the New Middle Class. The concept of Precariat first introduced by French sociologists in 1980s to define temporary and/or season workers (Standing, 2011:24). Standing (2011: 26), describes the concept of Precariat as including those individuals who lack the following seven securities formerly enjoyed by conventional industrial workers of the post-World War II era: Labor market security; employment security -protection against arbitrary layoffs, regulations on recruitments and layoffs-; job security; security in the workplace; security on the reproduction of qualifications; wage security; security of representation. In the contemporary capitalist system where massive unemployment is structuralized, the class condition characterized by temporary insecure employment can be defined as Precariat (Bora, 2014; Bora, 2010). As labor become decentralized, Precariat presents the profile for the white-collar workers, subcontracted workers and the plaza workers whose unionization became impossible (Bora, 2014; Bora, 2010). Another factor that differentiates the precariat from the worker or middle class is that, the individuals of precariat do not hold an occupation based identity (Standing, 2011: 29). That's to say, these individuals do not have a sense of belonging to an established occupational community, a sense of solidarity with their fellow class members since their occupation are mostly unpromising and excluded from the collective memory (Standing, 2011: 29). 
The employment regime based on prekariazation imposes individuals a myth of constant change and renewal. The glorification of a lifestyle that consist of changing jobs, cars, houses, cities every two three year, the images of plaza office is highly contradictory with the realities of actual workers who try manage their livelihood with limited income. The discrepancy between daily routine and the overrated lifestyle of the wealthy white collar professional, provoked competition and the isolation it brings, unemployment, insecurity and low wage comprise the problems of the white collar workers (Bora, 2014; Bora, 2010). For the defined precariat class to struggle against these problems within the capitalist system, they need to organize in a flexible fashion and the field for political struggle pluralizes. The empirical studies on Anti War on Iraq demonstrations, Seattle Protests, the Occupy movement in New York, reactions after the Madrid bombings, demonstrate that, the majority of the participants seem to be the white collar workers that can be identified as precariat who are non-regular workers, plan all their lives for their career but at the end face a precarious future, mobilize through cell-phones and social media, present a creative form of reaction with humorous slogans and performance shows (Palczewski, 2001; Boutreau, 2002; Carty, 2011; Fominaya, 2013).

However, different from the previous new social movements, people start to realize that these problems are all different dimensions of the neoliberal economic system. The people of different identities, varying concerns and agendas gather in the central urban settings to point to the main source of the problems. These recent movements not only forming connections between the groups and individuals but also influence and connect similar movements in other geographies. Therefore while discussing the new social movements of the post 2000s we can talk about a global civil society that mobilize with similar concerns, raise similar questions and employ similar strategies.

At this point it can be assumed that as the issues of women rights, human rights, unemployment, environmental problems become sensitive issues within the international arena; new social movements based on identity and heterogeneity become a new form of societal force. While some of these movements try to introduce a survival strategy, more radical anarchic groups display a role similar to the revolutionary role of the previous working class. Looking from this prism, the new modes of exploitation of the neo-liberal system paved the way for new forms of reactiveness and the ground for these reactions to be 
managed under the leadership of one group (namely the working class) has been eliminated. As the various interest groups unite against the different hitches of the current system, join the social movements and raise their voices for the transformation of the system. This shows that the subjects under the exploitation of the hegemonic system, despite all the fragmentation can take a common action.

\section{Mapping Gezi Park Resistance: Issues, Values, Actors and Mode of Action}

This section entails a comparative analyses of Gezi Park Resistance in terms of its beginning, the main issues and objectives that drive the protestors to the streets, who the protestors are and the means of the Resistance with regard to Tahrir Square Demonstrations, $15^{\text {th }}$ of May Movement in Spain (15M), Occupy Wall Street (OWS), EuroMaiden in Ukraine within the perspective of New Social Movements as a paradigmatic category.

Melucci (1996: 102-103) theorizes the new social movements common characteristics in a tripartite fashion. His first emphasis is on the variety of the issues addressed in the movements. In fact as observed during the Gezi Park Resistance, there was a wide variety ranging from environmentalists peaceful and environment focused actions to conflict oriented actions of identity and political groups. Secondly, these new movements are indifferent to the political system and reluctant to claim political power. As seen in the discourses put forward during Gezi Park Resistance, the participants kept their distance from formal party politics, party representations and ideologies, however the slogans were calling the government to resign the objective of the activists was not to seize power but the main issue was the neoliberal politics of the government and their environmental, socio-economic implications. According to Konda (2014: 14) statistics, $78.9 \%$ of the protestors stated that they do not have any affiliation with any political parties, associations, foundation and any other civil society organizations. Furthermore, $93.6 \%$ of the protestors stated that they are present as an ordinary citizen and only $6.4 \%$ was at Gezi Resistance representing a group and/or organization. Research on the social portrait of Euromaidan participants conducted by the Democratic initiatives foundation and Kyiv International Institute of Sociology on 7 and 8 December among randomly selected 1037 participants (Bekeshkina and Khmelko 2013), revealed that $92 \%$ of them did not belong to any political parties or NGOs. Only 5\% came to the protest following the call of opposition leaders. Thirdly, the new movements challenge the public/private division. Issues that are considered to be in the private sphere and not included 
within the scope of high politics such as gender rights, child abuse, environmental problems, abortion, and alcohol ban are carried to the public sphere during the social movements. Particularity, solidarity, participation, direct action and refusal of representation are the common characteristics of the contemporary new social movements that also Gezi Park Resistance shares (For more information on contemporary collective actions see Melucci (2002), Challenging Codes pg: 71-103).

\section{How the Resistance Started: Backgrounds and Beginnings}

In this section, the street resistances that started at the Taksim Gezi Park and spread to central neighborhoods of Istanbul and other important urban centers throughout Turkey between $28^{\text {th }}$ of May and $19^{\text {th }}$ of June 2013 will be analyzed. The discussion will revolve around how the Turkish government's neo-liberal policies constitute the dynamic for these actions. From this point of view the main argument is that, the AKP government privatized the urban settings, public spaces under the so called "gentrification projects" in pursue of establishing a presence in the neoliberal order. The citizens and urban stakeholders who do not have a say in these transformation processes, with the demand for right to their city and urban life turned their oppositionary voices into a social reaction that has been previously experienced in Seattle, Wall Street, London, in major cities of Spain and Ukraine.

The entrance of construction machinery to Taksim Gezi Park and the demolition kick off originated a massive resistance movement that hasn't been witnessed before in Turkey. The course of events that resulted in raising these anti-governmental sentiments started with the regime becoming more openly authoritarian and sociality conservative (Önal, 2015: 15). 'Pressures on organized labor, legislation that limit women' rights, increase in the killings of women and transgendered people, increase in the number of political arrests from 60 in 2012 to 400 in 2013, increase in hate crimes, increase in police brutality, top down planning" disseminated dissent across the half of the society (Önal, 2015: 15-16). In fact the hints and signals of Gezi Park Resistance were hidden in the previous demonstrations against hydroelectric power plants (HPP), the demolition of the movie theater Emek Cinema, also a historical landmark in Beyoglu, İstanbul, reactions against the construction of Third Bridge and the Third airport, and reactions against the gentrification projects, demonstrations of teachers, medical sector employees and doctors. Up until the 1980s the movements organized by student groups and strong unions mobilize around left-right dichotomy, having mostly 
macro level political demands and struggle for political domination in their agenda. After the 1980s, limited, local and isolated reactions draw the attention, which are based on ethnical, religious, gender, and environmental issues. The novelty of Gezi Park resistance in the Turkish social and political landscape lays in the fact the identity groups with differing agendas and even conflicting interests collectivized and mobilized an extensive movement. The clues of this movement are hidden in the pathway of globalization and neoliberal accumulation of capital; therefore it can be useful to briefly mention this process' reflections on Turkey. In that case Gezi Park Resistance presents divergence from previous forms of new social movements.

The expansionist character of global capital manifest itself in the construction of shopping centers and residences, subcontracted and unregulated mines, HPP constructions which contain the power of destruction of their surroundings and destroy the lives. The neo-liberal accumulation process also directs the government towards homogenizing and totalitarian social engineering (Sınır, 2014: 228-229). The metropolitan areas of Turkey have been going through a gentrification process leaded by TOKİ. This gentrification process is a dimension of commodification by the free market rather than beautification of the urban settings. In this process, the long established settlement areas, historical, cultural and geographical landmarks are transformed and opened to the use of the global capital despite the inhabitants' opposition to the process (Ergun, 2014: 2076-278). The historical buildings, especially in Beyoglu and Taksim as in the case of Emek Cinema all turn into shopping centers or hotel after the renovation. The last green areas at the surroundings of Istanbul, are being destroyed for the Third Bridge and airport construction, the historical neighborhoods are being evacuated from its inhabitants and opened to the service of the capital owners. All these transformation are the result of the efforts for joining the neo-liberal competition with Istanbul. However, the urban dwellers and the stakeholders of the city are being excluded from all the decisionmaking mechanisms while the decisions directly intervene their own everyday spaces (Ergun, 2014: 282).

In fact what triggered the Gezi Park Resistance is the hegemonic discourse and practices that constantly intervened the life-styles and altered the living spaces of the city residents. The last straw was the construction project of shopping mall-mosque complex replacing the last remaining park of Taksim which was a part of a massive urban renewal project. The capitalist group that would benefit from this project agreed with Prime Minister on the transformation 
project of Taksim, also supported by the liberal Islamic discourse that stigmatized Taksim and the lifestyle it represents with crime and immorality. After the start of the project urban planners, students of architecture, professional groups and various democratic initiatives camped in the park for its preservation. On 28 May 2013, without official permission, the construction machines entered the park and started the demolition illegally. At the dawn of the $29^{\text {th }}$ of May, while the camper protestors were far asleep in their tents, the police attacked with tear gas and water cannons setting the tents on fire. The excessive brutality against the peaceful environmental groups as the "good kids" that are not very common actors in the street demonstrations, far passed the tolerance limit of the people and at the evening of 29 May 2013 thousands march on the streets. Then Prime Minister's provocative discourse and the increased violence by the police spread the resistance to other cities of Turkey.

\section{Issues, Objectives and Values}

When the diversity of the participants to the Resistance and the variety of their agendas are considered the Gezi Park Resistance involve some parallels to the New Social Movements discussion. For a better elaboration, it would be useful to refer to the findings of Gezi Report conducted and published by research institution Konda. The survey conducted with 4411 participants to the Resistence of only those who were within the territories of Gezi Park. Even though the survey excludes the wide range of street demonstrators in Istanbul and from other cities still gives a certain understanding as to the nature and dynamics of the movement. According to the findings published by Konda (2014: 18), 58\% of the protestors came to the park to protest against the limitations to liberties, $37.2 \%$ to resist against AKP and its policies, $30 \%$ to show their reaction to Erdogan's declarations. Taking EuroMaidan movement in Ukraine for instance, "Research on the social portrait of Euromaidan participants conducted by the Democratic initiatives foundation and Kyiv International Institute of Sociology on 7 and 8 December among randomly selected 1037 participants (Bekeshkina and Khmelko2013), while the three most common reasons for coming out on the streets were police repressions and in particular - the beating up protesters on the night of 30 November ( $70 \%$ of respondents), the president's refusal to sign the Ukraine-EU association agreement (53.5\%) and a desire to change life in Ukraine (50\%)" (Ryabchuk, 2014: 131).

When Hardt and Negri's notion of Multitude is taken into account, environmentalists, secularists, Alevis, homosexuals, those who are against the alcohol and abortion limitations, 
unemployed, students, Kurdish people, football fans are in fact singularities carrying the fragmented identities of the postmodern society. According to Konda statistics (2014: 19), $34,1 \%$ of the protestors came to the park for liberties, $18,4 \%$ to claim rights and to protest against violations, $9,7 \%$ to protest against dictatorship and oppression, $9,5 \%$ for the resignation of the government, $8 \%$ for peace and democracy, $6,2 \%$ to protest the police violence, $6,1 \%$ for support and solidarity, $4,6 \%$ to protect the trees and the Gezi Park Square to avoid the construction, $3,2 \%$ to challenge the system and for revolution, $2,5 \%$ to be heard. When this diversity of the participants of the Resistance and the variety of their agendas are considered the Gezi Park Resistance involve some parallels to the contemporary New Social Movements. As can be inferred from the statistics, the Gezi Park Resistance provided the arena for these singularities to engage in a common action (Hardt\&Negri, 2004). As Konda's Gezi Report findings suggest, $87 \%$ of the protestors consider themselves among those groups who are faced with human rights violation (Konda, 2014: 15). Furthermore, according to Keyder, "Almost all the protesters in Gezi Park were young people with no direct experience of military rule or state repression. They were the beneficiaries of economic growth and greater openness to the world. They now wanted the basic rights that they knew existed elsewhere: they wanted to be able to defend public space against neoliberal incursion, and they refused to live under the authoritarian guidance of a self-appointed father of the country" (Keyder, 2013: http://www.lrb.co.uk/blog/2013/06/19/caglar-keyder/law-of-the-father/ Accessed on 11.11.2015).

Taken into account within the framework of New Social Movements, The Resistance became an arena in which the actors preserving their own singularities and demands engaged in a collectivist and solidarist form of activism. This solidarist character of the Resistance manifest itself in the cases where different contradictory groups protect each other from the police brutality, leftist student groups forming human chain around the anti-capitalist Muslim groups against the police attack during the groups do their prayer, rival football fan groups' solidarity and collaboration behind the barracks against the police attacks and earth tables where Revolutionary or anti-capitalist Muslim groups and seculars, atheists shared their food. Kingsnorth in his work entitled "One No, Many Yeses", define the notion of multitude in the New Social Movements as the groups with multiple baggages and claims gather around one "no" to the neo-liberal order and its all cultural, political, economic and environmental dimensions (Özatalay, 2014: 172). 
From this perspective The Gezi Park Resistance can be considered as the gathering point of multitude of yeses to "right to city", "right to liberty and security", "existence of different ways of living", "freedom of expression", etc. (Önal, 2015: 15) under one no to the government's patronizing policies, increased authoritarianism and neo-conservative discourses that are shaped according to the expansionist capitalist order that is paving the way for the economic, social, cultural and environmental deterioration. This one "no" in a way reflecting the common enemy is key to formation of solidarity between the actors with diverse affiliation. As also pointed out by Önal (2015: 16), the discriminatory discourse by the government officials and then Prime Minister Erdogan, -who claimed during a public speech that they"hardlykeepth $50 \%$ at home" threateningtheother $50 \%$ of thepopulationreinforced the "we-feeling" among the protestors while widening the polarization between "us" (referring the pro-government strata of the population) and "them" (the dissident strata of the population).

Tahrir Square demonstrations started on 25 January 2011 and after 18 days of revolt, resilience and occupation, former president Hosni Mubarak resigned from the government. As Shwartz (2011: 35-40) mentions in discussing Tahrir Square, the demonstrations were against the authoritarian government that exhausted brutal police force against the people throughout its rule Authoritarian regimes nurture the financial standing of the major capitalists interests, Egyptian business groups through privatization of public assets, structural reforms (Mahmoud, 2015: 11). The course of the demonstrations and the events led to the demonstrations reveal that the mafia-like police structure and its extreme oppression on the people played a vital role in the mobilization of Tahrir Square Uprisings (Shakr, 2011; Northedge, 2011; Ghosbashy, 2011). The police served not as providing the public order and the security of the people but served for the government's well-being as repressing every dissent against the authority and its pro-capitalist policies. Similar to Gezi Park, gentrification projects of Tahrir and Cairo to drive out the poor for the elites and consumption patterns were one of the objective of the participants. Therefore it could be assumed that the Tahrir protests also gathered people with many yeses only for one no tot the government that represented and protected the neo-liberal interests of the capitalists.

Similar to Tahrir Demonstrations, anti-austerity $15 \mathrm{M}$ movement on $15^{\text {th }}$ of May 2011 in Spain, people were drawn to the squares because of lack of confidence in politician, political 
corruption, inability of government to handle economic crisis (Castaneda, 2012: 310).According to Eurobarometer Survey, $86 \%$ of the Spanish respondents stated that the government handled the economic crisis poorly (Castaneda, 2012: 310).As Hughes (2011: 413) argues, the conflict was directed towards the two pillars of globalization namely the neo-liberal economy and the liberal democracy as well as the institutions that promote it. To illustrate better the objectives and values of the M15 movements, the proposals adopted by the movements actors could be helpful: "Elimination of the privileges enjoyed by the Spanish political class a series of labor market reforms; the right to housing; high quality in public services; public regulations; reform of the tax system; participatory democracy and cuts in military spending" (Hughes, 2011: 412). So it can be suggested that the main issues mobilized the M15 movement were economic ones.

During Occupy Wall Street (OWS) that started on $17^{\text {th }}$ of September 2011 in Zucotti Park, New York people were also united by focusing on economic inequality and political system that serve the few 1\% at the cost of the Many (Milkman et al, 2013: 196). Just as Gezi Park and M15 OWS had no specific objectives and demands so that anyone can come into the movement to see that many share similar problems and grievances: unemployment, debts, lack of housing, lack of health care, environmental problems and so on (Milkman et al, 2013: 195). The main focus on OWS as well as M15 was reclamation of land and housing (Choy, 2012: 43). The main problem behind the OWS and M15 was generally the financial sector and real estate market that dubbed people into deep debt and in times of crisis put people on the streets, closing the family homes (Choy, 2012: 43).

The main idea behind both three movements (Gezi Park, M15 and OWS), people who live in the area are the best keepers of that area. The struggle was for that not the big corporations, capitalists and politicians determine how people manage where they live and how they live (Choy, 2012: 43).

The EuroMaidan protests started in Ukraine as a civic initiative. Being distrustful to the existing political parties and leaders, protests directed at the government for pursuing proRussian policies which represented authoritarian communist order of the past (Ryachbuk, 2014: 127-130; Önal, 2015: 22). All in all, for the Ukranian protestors, the pro-Russian 
policies and government's distance to Europe, distrust to opposition parties and dissent to authoritarian rule mobilized people to take action against the government.

The question is "what do protestors want to get rid of and bury in the past" (Ryabchuk, 2014: 4, Önal, 2015: 22). Quoting from Önal:

"Although there is a tone of revolution in both Gezi Park and EuroMaidan, the focal point of these protests was their anti-authoritarian and anti-governmental characteristic. Their aim was not to overthrow the system altogether, but to change power relations in favor of a civil society that is capable of integrating a plurality of voices, vis-à-vis, a corrupt and authoritarian government together with a demand for viable political institutions and egalitarian and pluralistic representation. The demand for engagement and autonomy and the demand for the transparency of the state unite these protests and connect them with the regional and global frameworks as NSM that are organized around identitarian politics and consensual social relations.” (Önal, 2015: 22)

From the brief analysis of the five movements it can be suggested that "the unifying frame for the mobilization: the simple and straightforward focus on inequality united people who disagreed on other issues" (Calhoun, 2013: 33). The distrust to politicians and governments derive from the realization that they serve to corporations and the wealthy not the ordinary people (Calhoun, 2013: 33). The economic aspect of these movements lie in the fact that the governments facilitate in the concentration of wealth through tax breaks, bailouts, using common assets for private profit (Van Gelder, 2011: 3). What is more, instead of investing this wealth and profit to provide jobs and produce goods and services they invest in mergers, acquisitions and speculations (Van Gelder, 2011: 3). This system make people find themselves in low wage jobs without prospects for a secure future (Van Gelder, 2011:4). This is what is being observed in these five Occupy movements, that the participants agree on the fact that the guaranteed life standards of the middle class way of life is being eroded, uncertain future with the high risk of poverty is awaiting (Van Gelder, 2011: 4).

If Gezi Park protest were compared with the M15, OWS and Tahrir Square movements in terms of objectives and values, it could be suggested that the main focus was on equality and good life. The participants all voice that every area of life is being captured by the capital. 
ON that case New Social Movements in the form of Occupy movements of the late 1990s and 2000s are different from the previous ones. The participants don't mobilize according to their identity and the movements are not particularistic and fragmented. On the contrary, different groups gather together to protest against the current economic system and its social, environmental and political impacts.

\section{Actors, Organizational Structure and Repertoire}

When the social composition of the protestors are considered, it can be claimed that, "the protestors are representative of a newly emerging middle class, dissatisfied with the 'neoliberal authoritarianism' of the ruling AKP and look for new guarantees for their way of life, for their environment, for their right to the city; and they resent violations of their personal and social space" (Önal, 2015:10; Keyder, 2013: http://www.lrb.co.uk/blog/2013 /06/19/caglar-keyder/law-of-the-father/ Accessed on 11.11.2015).

In scrutinizing the social composition of the Gezi protests, Konda's Gezi Park Report based on the survey research conducted during the Resistance would give useful insights as to the nature and composition of the Resistance. According to the statistics published by Konda, $78,4 \%$ of the protestors were between the ages of 18-35 (Konda, 2014:6), the gender distribution was slightly in favor of women with $50,2 \%$ to $49,2 \%$ male (Konda, 2014:6) In terms of education level, $55,7 \%$ of the were university or master's graduates whereas the percentage of university and master's graduates for Turkey is only 12,9\% (Konda, 2014: 9).

When the class positions of the contemporary New Social Movements' actors in general and Gezi Park Resistance actors in particular are assessed, it can be claimed that the major unions and organized working class to a large extent stayed distant to the resistance (Özatalay, 2014). According to statistics published in Konda Report, the percentage of workers within the Turkish society is $15 \%$ whereas the percentage of workers present in at the Gezi Park Resistance was only 6\% (Konda, 2014: 11). However it should also be noted that the Konda Survey was conducted only at the Gezi Park whereas riots, rallies and resistance was spread all other central districts of Istanbul where the members of the worker class might be actively participating the protests. As mentioned earlier rather than an organized massive workers rally, the resistance movement was mostly composed on those who object the social assertiveness of the government authorities, the white collar workers who suffer the current 
socio-economic system, who want their lifestyles and personal preferences to be accepted, those who are unemployed, environmentalists and so on.

So when the Gezi Park Resistance activists are considered, it could be asserted that it encompasses the victims of the neo-liberal system, the plaza employees whose socioeconomic conditions are similar to those of the industrial workers but they also face a precarious future despite their qualified labor and good education, service sector workers, students and those groups that politicize the issues related to life style, identity belongings and environment. Similarly, the participants of Tahrir Square Demonstrations, 15M and OWS were propelled by excluded groups such as students, unemployed, underemployed, low waged, precarious, young people, retired, ordinary citizens, intellectuals, etc. (Hughes, 2011: 409; Schwarz, 2011; Choy, 2012; Milkman et al., 2013).

The strategies for mobilization through the internet and mobile phones, passive resistance strategies like Standing Man, young man reading a book against the police barricades, the guitar player, the piano player at the heart of the square, the humor on the graffiti and on the slogans are highly similar to their counterpart movements that flourish in other geographies. Strikingly, the same pianist with the same piano performed in Taksim Square during Gezi Park Resistance also performed in Ukraine during Kiev protests.

"There was a worldwide wave of protests that gave added weight and significance to each. Visual media shared images of urban occupations that brought inspiration and circulated tactical ideas" (Calhoun, 2013: 28).

As Castells puts it, modern social movements are global, leaderless, collective and virtual before occupying streets (Castells, 2013:11). When we look at the way that how Tahrir Square, M15, OWS, EuroMaidan and Gezi Park movements all started and developed, it is pretty obvious that they share the same basic structural features. In Egypt, "We are all Khaled Said" - who was brutally beaten to death by the police for posting a footage on police corruption on June 6, 2010- group organized the Day of Rage on January 25. Their call to take stand against torture, corruption, poverty and unemployment mobilized thousands of young Egyptians (Northedge, 2011:6). The way to resist was convened through social media. $15 \mathrm{M}$ movement of Spain for instance, was organized through a web-site platform 
“Democracia Real Ya” supported by 200 organizations (Hughes, 2011: 408). This website was key in the framing the action, developing a common sense of identity and purpose (Hughes, 2011: 408-409). Furthermore by definition the 15M movement was grassroots, nonparty, non-violent citizens' movement, adopting a decentralized structure whereby the decisions were reached collectively through free exchange of information and respect for diversity (Hughes, 2011: 411-412). Inspired by 15M and Tahrir protests, there was a call from Adbusters magazine to show up at Wall Street on September $17^{\text {th }}$ and bring a tent. Few thousand people gathered to name and point to the source of the crisis of our time on Wall Street (Gelder, 2011: 1). OWS also identified itself as a "leaderless resistance movement with people of many political persuasions, refusing to articulate policy demands or to embrace old ideologies" (Hartcourt, 2011: 1).

In terms of repertoire and mode of action, three common features of the five mentioned movements come up: setting up camps and occupation of city squares; emphasis on nonviolent resistance; theatrical and artistic performances.

As in the cases of M15, OWS, Tahrir as well as Gezi Park, occupation of significant urban settings for days and weeks, setting up tents and camps engender a sort of exchange and solidarity between the activists (Shakr, 2011: 16). Occupation turned the urban settings into non-commodified spaces where activists and participants to the movement relate to each other outside of the market (Milkman et al, 2013: 196). Occupation was a strategy for claiming right to public spaces that are gradually reducing especially in high profile urban centers. On the one hand Tahrir Square and Cairo was undergoing a series of gentrification processes similar to Istanbul and Taksim region which was also driving its inhabitants to the outskirts. On the other hand in Spain and USA, the real estate sector and financial crises made many individuals who are unable to pay their debts become homeless, driving them out of their family homes and neighborhoods. Hence the occupation of spaces with tents and camps can be regarded as reclamation of land that once belonged to the fellow citizens and now taken over by the capital (Calhoun, 2013; Milkman et. al., 2013).

The occupation tactics also facilitated in forming connections, webs and mutual awareness between different groups and different people (Calhoun, 2013: 30). To give an example how 
occupation movements facilitated in forming these connections, Shokr (2011:16) depicts his observations from Tahrir square:

"Over the course of 18 days, the plaza had turned into a veritable polis, where people were bound together by more than a common political demand. Together, the people of Tahrir forged a society, marked by interdependence and collective decision-making- at times even hierarchies. They were preoccupied with everything necessary for the smooth functioning of a social order, from basic necessities -food, shelter, security -to questions of political strategy. Even the most mundane acts- sweeping the streets, preparing food, pitching tents became moments of inspiration that proved the people's ability to sustain themselves, despite the regimes attempts at sabotage. Daily struggles to hold the space and feed its inhabitants, without the disciplined mechanisms of an organized state, were exercises in democratic process. It was through these everyday practices that Tahrir became a truly radical space."

$15 \mathrm{M}$ presents a striking example of how thematically organized camps facilitate in the development of the common sense of awareness between the people. These occupations and camps provided the excluded to raise their voice in series of debates on various issues (Hughes, 2011: 412). Protestors in organized commissions formulated proposals to be voted on in daily assemblies. Decisions then e-mailed to the main camp in Madrid (Hughes, 2011: 412). A similar organization was tried after the movement was dispersed in Gezi Park. After the Occupation was dispersed by the police, people took it to the local parks of their neighborhoods and held forums in major cities of Turkey. However these forums were not effective and did last only for few weeks. These structures can be considered as efforts of especially the young citizens who are frustrated by the liberal democratic system and distrustful to the current political structure to find an alternative way of governing.

The second common aspect of the five movements as mentioned was their emphasis on onviolent, peaceful passive resistance. In all these movements, Tahrir Square, M15 OWS, EuroMAidan and Gezi Park resistance, police brutality was the key mobilizing issue. For instance, many photographs disseminated among people who became furious to with the images where peaceful young individuals were attacked by police, setting their camps on fire, attacking with tear gas and water cannons the peaceful crowds also including children, 
disabled people and elderly. The findings of the Gezi Report by Konda reveal the fact that $49,1 \%$ of the protestors entered the ranks of the Resistance after they saw the police brutality. Calhoun (2013: 32) also mention that for OWS, "police efforts to disperse the crowds provide the most influential images in protest mobilization". Similarly the M15 movement, OWS and Tahrir Square movements, police response to non-violent groups revealed the excessive police violence that legitimized the movements in the eyes of the general people and increased the support and participation to the movement (Calhoun, 2013; Castaneda, 2012: 315-316; Northedge, 2011; Shokr, 2011). The police brutality meant to the people that state power was there to protect the interests of the corporate capital against the citizens (Calhoun, 2013: 32). People who were reluctant and kept distance to the previous movements because of the destructive acts of the activists, felt the need to support and participate in the peaceful protests.

\section{Implications of Gezi Park Resistance for Political Communication}

For considering the implications of Gezi Park Resistance for political communication, three main points unfold; conventional mass media appearing with its incapacity, ignorance and the voice of the hegemonic governing power; the emergence of new media for conveying the political demands and strategies of the resistance movement and finally new tools and performative acts for claims making of the protestors. Online communication and internet are focal to the organization of the new social movements. As Langman (2005: 54) mentions media has an essential role in social movements, in the dispersion of news, ideas, planning strategies and coordinating with other groups and influencing wider publics.

Before elaborating the role of media during Gezi Park Resistance in relation to political communication, it would be useful for the sake of the argumentation a brief discussion on the role of media in new social movements. Communication as interchanges between individuals produce and reproduce the common experiences, grievances and sense of injustice. If people accept the existing order as legitimate and as long as there is collective ignorance, individuals would not form a collective movement to challenge the existing order no matter how much they are victimized by it (Das, 1981: 130). In other words, realization by the people of shared experiences through exchange of ideas engenders the foundations of collective action. Accordingly, the role of communication in the emergence and formation of collective action is of considerable importance. As Das (1981: 139) suggests, the development of mass 
communication may have facilitated the growth of social movements in various ways such as creation of diffuse collectivities, creation of solidarity and disseminating undiscovered social issues (Das,1981: 139).

Similar to Das's emphasis on the role of communication in the genesis of social movements, Castells (2013: 200) underline the fact that the struggles, actions and organizations of 1990s anti-neoliberal movementsaredeveloped by means of online communication. In fact as Langman (2005: 43) suggests, technologies of communication have long been integral to new social movements and the global character of these movements and worldwide proliferation is made possible by the Internet. Divergent groups through the internet conveyed their messages, opinions and discussions to a wide range of audience(Langman, 2005: 42). As for the information communication technologies' (ICT) relationship with social mobilization it can be asserted that, it provides low-costs, easy access to networks as well as immense flow of information. Furthermore, technology enables participation to social mobilization structures by promoting a collective identity. As mentioned earlier, individuals from various walks of life realize their common grievances and grow a sense of belonging to a larger community based on adversity and grievances. The speed and flexibility of the ICTs, enable to foster a collective identity across a dispersed population (Garrett, 2006: 205).

In elaborating the anti-globalization movements Castells (2013: 203) mention that the main activists of these movements target to reach the mindset of the general people. Media is the main vehicle for reaching the masses. Concomitantly, those movements, which attract the attention of the media, achieve disseminating the values and ideas to the public. ICTs are also producing changes in repertoires of contention, allowing activists to engage in new forms of contentious activity and to adapt existing modes of contention to an online environment (Langman, 2005: 55). So the New Social Movements actors adopted strategies that are worth for media to news report such as occupying public spaces, theatrical performances and peaceful resistances. Examples of festivals, street parties, street theaters, civic disobedience acts that are also a manifestation of global youth culture becomes a way of collective use and sharing of public spaces through creativity and performance (Castells, 2013: 204). The colorful, witty, creative images from these movements become iconic and spread to wide range of people especially through social media. Therefore more people could familiarize themselves easily with the movement. 
In the manifestation of ICTs and social media in particular as the medium for mobilization, the incapacity and hegemonic aspect of conventional mass media is also important.For instance, Carroll and Ratner (1999) refer to the asymmetrical relationship between social movements and mass media. Production of the news in the mass media is described as hegemonic system of power an media at the center of mass communications network have a wide range of options for making news whereas movements have limited options for conveying their messages (Carrol \& Ratner, 1999:2, 28). This asymmetry puts media in a favorable position in contrast to the movements. Within this asymmetrical relationship, movements need the media for three main purposes: "to mobilize, to validate their existence as politically important collective actors, and to enlarge the scope of conflict" (Carroll \& Ratner, 1999:3). To reduce or reverse the dependency, movements present dramatic events to attract media attention or making use of alternative media (Carroll \& Ratner, 1999: 28).

The argument put forward by Carroll and Rattner (2009: 28), that the asymmetry in movement-media relation resulting in making use of alternative media outlets is prevalent in Gezi Resistance. The salience of conventional mass media to the Resistance had an unprecedented consequence of generation of a new consciousness of a counter-hegemony (Kurtuluş, 2014: 270). This counter-hegemonic consciousness manifest itself in stigmatization of media as "penguin media" for broadcasting documentary at the time of the climax of the protests, by the protestors and supporters. Furthermore, the discussion programs broadcasted on mainstream mediathat give space to repressive, ignorant and pejorative discourses of the representatives of hegemonic political powers, as well as giving space to misinformation and provocative voices, drove people to alternative media sources. In these alternative media sources a new language of political communication challenging the hegemonic discourses emerged. Meanwhile in the hegemonic mass media, organic intellectuals in Gramscian terms in their analysis and comments presented the resistance movements by alienating the movement from its political context and referring the protestors as apolitical (Kurtuluş, 2014: 270).

In order to posit a better picture of how media has facilitated in the perception of Gezi Resistance and shaped its implication on political communication, it can be referred to the findings of the survey conducted by Konda during the Resistance. As in the case of Gezi Park Protests, one way stream of the mass media, their hegemonic position in producing and 
constructing news, deciding which information to convey and how, frustrated the protestors as well as shaped the dominant public opinion. According to Konda statistics (2014), $70 \%$ of the participants to the survey obtained the first information from television broadcasts and about $20 \%$ of them obtained the first information on the internet and through social media (Konda, 2014: 25). For elaborating the role of media in the formation of public perception and attitude towards Gezi Resistance, the statistics are quite striking. The news sources highly facilitate in perception formation about the events of Resistance, for instance those who follow the pro-government media agree that the protestors were at fault from the beginning and shouldn't have resisted the government by 60\% (Konda, 2014: 40). Furthermore $84 \%$ of those who agree that the protestors were wrong from the beginning follow the information from television whereas only $11 \%$ get informed by the internet and social media (Konda, 2014: 42). From the statistics, the asymmetrical relationship between the mass media and social movements specific to Gezi Resistance is quite apparent. However it should be noted that, the audiences cannot be considered as passive subjects that are only shaped by the one way communication of information and ideas from the media. Rather, individuals chose to follow the media representing similar world views and ideologies reinforcing and reproducing their own mindset. So the statistics only state the fact that, the mass media predominantly represent the hegemonic order and followed by those who are not critical and/or in opposition to the hegemony.

Gezi Park Resistance in various aspects bring novelty in terms of political communication. For the discussion of Gezi Park Resistance's implications for political communication, the role of internet and conventional mass media appear to be the key elements. First of all reactions to conventional mainstream mass media gained impetus and more people come to realize that the information conveyed through conventional mass media are questionable. Many participants to Resistance who have lived in the western provinces and of middle class youth have questioned the information they have obtained from mass media on the previous movements and police interventions. Some alternative television channels and social media, which are believed to convey true and up to date information, gained popularity and increased its followers. Main stream media and popular channels were discredited and strongly criticized for broadcasting irrelevant documentaries and programs during the protests and being indifferent to the massive protests of the people and the violent clashes with police taking place a step away from their building. Hence, from the attitude of mass media towards 
the Resistance, it was realized that the media that claimed to be free was not so free either. So a new way of free communication emerged and Gezi resistance revealed the importance of new communication technologies as political demands were made on social media. This implied the importance of effective use of social media in political communication. Furthermore social media especially twitter was defined as troublesome by the then prime minister who does not have the means to control and censor as he does for mainstream conventional media. The protestors organized at the micro level, call for help and solidarity, words spread through twitter to hundreds and thousands of people. Images of protests, lists of requirements, images of injured and lost, proves of police brutality and other means for the movement spread through social media, otherwise would be impossible with mainstream media. While the mass media for some exceptions was blind and deaf to the police brutality, people watched the current happenings from different cities from live stream domains on the Internet.

Gezi park protest also revealed the misappropriation of social media as the excessive misinformation conveyed through various channels, irrelevant images, and false announcements for provocation was not possible to prevent. Individual warnings were some limited attempts for commonsense and not falling for misinformation and provocation.

\section{Conclusion}

Three main concluding points can be drawn from the brief analysis of the five new social movements of Gezi Park Resistance, Tahrir, 15M, OWS and EuroMaidan. First of all, it can be inferred that the social movements that are based on claims for rights on identity and culture has shifted by the late 1990s and 2000s the new social movements mobilized by social and political concerns based on economic austerity. Therefore the main objectives and concerns of the people participating in these movements basically voice the social costs of the functioning of neo-liberal economic system in the forms of economic crisis, spreading of poverty, erosion of social welfare and middle class security, widening gap between the wealthy few and impoverished many. Also people held common grievances to the governments and political elites who serve for the well-being of the capital at the cost of the well-being of the people. For protecting the interests of the capital the governments turn into authoritarian rules using excessive police power in times of dissent. 
Secondly, the recent New Social Movements are highly global, inspiring each other in terms of strategies, objectives and tactics. As Castells mentions (2013: 196), these social resistance movements are connected to each other through Internet webs, media and discussion forums. Quoting from OWS's official website; “Occupy Wall Street is a leaderless resistance movement with people of many colors, genders and political persuasions. The one thing we all have in common is that We Are The 99\% that will no longer tolerate the greed and corruption of the $1 \%$. We are using the revolutionary Arab Spring tactic to achieve our ends and encourage the use of nonviolence to maximize the safety of all participants" (http://occupywallst.org, accessed on 17.11.2015).From the self definition of the movement summarizes the overall discussion presented in terms of the structure, objectives, actors of new social movements and their interaction at the global level.

As seen in the analysis, the participants of the five movements are those who are excluded and adversely affected from the functioning of global economic system, namely the neoliberal order and its social and political implications. The common issues in both movements were the inequality, poverty, claiming right to public spaces, neighborhoods, authoritarianism and abuse of the police. The diversity of the participants also reveal the fact that, people are drawn to the streets not based on identity and cultural politics. These recent movements are not issue specific and fragmented but gathering of many "yeses" against one "no". According to Castells (2013: 197), in understanding these movements it is important to look at the sources, values and objectives that make these movements happen rather than the characteristics of the participants.

Thirdly, from the theoretical analysis of Gezi Park Resistance that occurred between the $28^{\text {th }}$ of May to $19^{\text {th }}$ of June it could be concluded that, the Resistance share similar characteristics with other new social movements mobilized in other geographies. Therefore the Resistance movement cannot be analyzed independent of the phenomena of globalization in the new capitalist order. Briefly, the neo-liberal order of capital accumulation introduced new modes of domination and stratification. This new order commoditize all areas of life also introduce a flexible, decentralized mode of production, disseminating precariousness and insecurity to different geographies. The nation-states that want to articulate this process generate policies regardless of the interests, demands and desires of the individuals and the society. 
The victims of this expansionist globalization develop a new mode of social mobilization. These movements essentially bring everyday issues to the realm of politics; they can be characterized as temporary, not durable, distant to party politics, leaderless and unorganized movements. Considering the class position of the activists, they are different from the worker class whose actions are based on economic concerns and have a class consciousness, rather the activists considered to be from different fractions of New Middle Class who demand recognition of their life styles and direct representation.

From the analysis of the five New Social Movements the following assumption can be put forward:

- The main emphasis of these movements are on the economic austerity and deterioration of living conditions of the people.

- The main target is the global corporate capital, its neo-liberal order and their collaborating authoritarian political elites.

- The occupation as a movement strategy is vital for these movements

- Occupation and camps create a sense of solidarity between different groups and peoples.

- The movements' structure is composed of networks of loose ties.

- The movements from different geographies are deeply inspired and influenced from one another.

- The non-violent character of these resistance movements reveal the extremes of police brutality which also became a climax for the movements.

Consequently, evaluating the Gezi Park Resistance within the New Social Movements paradigm, the Resistance is significant in the Turkish social and political landscape by its unorganized, contextual and heterogeneous structure. These resistance movements were idealized by several academicians, journalists and politicians with the idioms of "Nothing will be the same as before", "Gezi Park Spirit", "Disproportionate Intelligence" regarded the movement as a transition point for the society, reinforcing their belief in the youth who are blamed as being apolitical. However while evaluating the Gezi Park resistance, one should also not ignore the social, political and economic developments after 2013 the reactions to these developments. Some efforts were made by organizing local platforms to continue the Gezi Park Resistance after the $19^{\text {th }}$ of June 2013, it should not be cast aside that the negative developments occurred after June 2013 did not generate a similar social reflex. The voice records that reveal a serious corruption scandal on $17^{\text {th }}$ December 2013, the mine catastrophe 
caused 300 deaths which was a result of deregulation and pro-capitalist policies of the government, the government's inaptitude in preventing the bombings in Suruç on $20^{\text {th }}$ of July 2015 and Ankara on $10^{\text {th }}$ of October 2015 that caused the death of hundreds of people did not evoke the "Gezi Spirit". The reason that the revival of the "Gezi Spirit" did not happen lies in the very characteristics of the resistance movement that the movement itself is flexible, unorganized and heterogeneous prioritizing momentary daily issues. From this perspective, the issues that caused the resistance movement such as the interventionist and totalitarian discourses of the government, increased insecurity and exploitation especially in the labor market, the environmental destruction are all amounted over time since the Resistance ended. Therefore for the future research on the new social movements it is highly important to evaluate the underlying dynamics of the fact that a second "Gezi Park Resistance" did not occur despite the amounting problems. 


\section{References}

Bora, T. BeyazYakalılarınIsyanınınArdında Ne Var? 10.04.2014 http://emekatolyesi.org/beyaz-yakalilarin-isyaninin-ardinda-ne-var\#.U7KgPha-ra4

Boudreau, V.(2002). State Repression and Democracy Protest in Three Southeast Asian Countries. In D.S. Meyer, N. Whitter, B. Robnet (der.), Social Movements, Identity, Culture, and the State (28-46). Oxford: Oxford University Press.

Calhoun, C. (2013). Occupy Wall Street in Perspective, The British Journal of Sociology, 64:1, 26-38.

Carty, V. (2011).Wired and Mobilizing: Social Movements, New Technology, and Electoral Politics. New York: Routledge.

Carroll, W. K.; Ratner, R. S. (1999). Media Strategies and Political Projects: A Comparative Study of Social Movements, The Canadian Journal of Sociology, 42:1, 1-34.

Castaneda, E. (2012). The Indignados of Spain: A Precedent to Occupy Wall Street, Social Movement Studies, 11:3-4, 309-319.

Castells, M. (2013).EnformasyonÇă̆ı: Ekonomi, ToplumveKültürKimliğinGücü. Istanbul: İstanbul BilgiÜniversitesiYayınları.

Choy, E. (2012). From the Camps to the Neighborhoods: A Conversation with Movement Generation. Race, Poverty and Environment, 19:1, 42-43.

Coşkun, M. K. (2007). DemokrasiTeorileriveToplumsalHareketler, Ankara: Dipnot.

Crossley, N. (2002). Making Sense of Social Movements.Buckingham: Open University Press.

Dahlgren, P. (2005) The Internet, Public Spheres, and Political Communication: Dispersion and Deliberation, Political Communication, 22:2, 147-162

Das, M. (1981). Social Movements, Social Change and Mass Communication, International Review of Modern Sociology, Vol. 11, No. 1/2 (Jan.-Dec. 1981), pp.127-143.

Demirkent, D., Baykan, T. (2010).Tanıl Bora

ileSöyleşi.http://www.birikimdergisi.com/birikim/makale. aspx? mid=639\&makale $=$ Tan\%FDl\%20Bora\%20ile\%20S\%F6yle\%FEi:\%20S\%FDn \%FDf,\%20Kapitalizm\%20ve\%20T\%FCrkiye

Durakbaşa, A. (2014). Gezi

DirenişiveTürkiye'deToplumsal/SiyasalTahayyülUfkumuzunAçılmasıİçinSosyolojiki zlekler.İçinde V.S. Öğütle, E. Göker (der.), Gezi veSosyoloji:

NesneyleYüzleşmekNesneyiKurmak (191-202). İstanbul: Ayrıntı. 
El Ghosbashy, M. (2011). The Praxis of the Egyptian Revolution, Middle East Report, No. 258, 2-13.

Ergun, C. (2014). KentselDönüşümeKarşıÇıkmak: KamusalıHatırlamakÜzerineBirkaç Not. İçinde V.S. Öğütle, E. Göker (der.), Gezi veSosyoloji: NesneyleYüzleşmekNesneyiKurmak(276-291). İstanbul: Ayrıntı.

Fominaya, C. F. (2013). The Madrid Bombings and Popular Protest: Misinformation, Counter-information, Mobilisation and Elections after '11-M' içinde J. Drury, C. Stott, Crowds in the 21st Century (17-35). New York: Routledge.

Garrett, K. (2006) Protest in an Information Society: a review ofliterature on social movements and new ICTs, Information, Communication \& Society, 9:02 (202-224)

Hartcourt, B.E. (2011). Occupy Wall Street's 'Political Disobedience', http://opinionator.blogs.nytimes.com/2011/10/13/occupy-wall-streets-politicaldisobedience/?_r=0

Hardt, M., Negri, A. (2004).Çokluk, ImparatorlukÇağındaSavaşveDemokrasi. B. Yıldırım (Çev.). İstanbul: AyrıntıYayınları.

Hughes, N. (2011). Young People Took to the Streets and all of a Sudden all of the Political Parties Got Old: The 15M Movement in Spain, Social Movement Studies, 10:4, 407413.

KONDA (2014). Gezi Raporu: Toplumun Gezi ParkıOlaylarıAlgısıve Gezi ParkındaKimlerVardı. Konda AraştırmaveDanışmanlık, 5 Haziran 2014.

Kurtuluş, H. (2014). KenteHakMücadelesindeSokağınİşgali, Sınıflarve Gezi ParkıDirenişi.içinde V.S. Ögütle, E. Göker (der.), Gezi veSosyoloji: NesneyleYüzleşmekNesneyiKurmak(261-275). İstanbul: Ayrıntı.

Laclau, Ernesto, Chantal Mouffe (1992). HegemonyaveSosyalistStrateji, Çev. Ahmet Kardan, DoğanŞahiner, İstanbul: Birikim.

Langman, L. (2005). From Virtual Public Spheres to Global Justice: A Critical Theory of Interworked Social Movements, Sociological Theory, 23:1 (42-74).

Mahmoud, A. (2015). Social Movements in Tunisia and Egypt, International Journal of Social Science Studies, 3:3, 8-20.

Melucci, A. (1996). Challenging Codes. Cambridge: Cambridge University Press.

Melucci, A. (2007). YeniToplumsalHareketler: SosyolojikBirYanılgı̈̈zerineDüşünceler. H. Erbaş (ed.), M. Coşkun (trans.), Fark, Kimlik, Sınıf. İstanbul: Eos. 
Milkman, R., Lewis, P., Luce, S. (2013). The Genie's Out of the Bottle: Insider's Perspectives on Occupy Wall Street, The Sociological Quarterly, 54, 159-228.

Northedge, L. (2011). Egypt: First Steps. The World Today, 67:3, 4-7.

Offe, C. (1985). New Social Movements: Challenging the Boundaries of Institutional Politics. Social Research, Vol. 52 No. 4 (817-868).

Önal, L (2015). Gezi Park and EuroMaidan: social movements at the borders, Innovation: The European Journal of Social Science Research.

Özatalay, C. (2014). Gezi Direnişi: Anti Kapitalist mi, Alter Kapitalist mi? içinde V.S. Öğ̈̈tle, E. Göker (der.), Gezi veSosyoloji: Nesneyle Yüzleşmek Nesneyi Kurmak (170185). İstanbul: Ayrınt1..

Pakulski, J. (2007). ToplumsalHareketlerveSınıf: MarksistParadigmanınÇöküşü. İçinde H. Erbaş (der.), M. Coşkun (çev.), Fark, Kimlik, Sınıf. İstanbul: Eos.

Palczewski, C. H. (2001). Cyber Movements, New Social Movements, and Counterpublics.İçinde R. Asen, D.C. Brouwer (der.), Counter Publics and the State (161-186). New York: State University of New York Press.

Ryabchuk, A. (2014). Right Revolution? Hopes and Perils of the Euromaidan Protests in Ukraine.Journal of Contemporary Central and Eastern Europe, 22:1, 127-134.

Schwartz, M. (2011). The Mass Strike in the Time of Neoliberal Globalization, New Labor Forum, 20:3, 32-43.

Şen, H. (2014).ApolitikliğePolitikBakmak. içinde V.S. Öğütle, E. Göker (der.), Gezi veSosyoloji: Nesneyle Yüzleşmek Nesneyi Kurmak (221-232). İstanbul: Ayrıntı.

Shokr, A. (2011). The 18 Days of Tahrir. Middle East Report, 258.

Sınır, Ş. (2014).Gezi, KürtlerveKanaatlerinKıyısındakiKırılganPolitikRepertuar.içinde V.S. Öğütle, E. Göker (der.), Gezi veSosyoloji: Nesneyle Yüzleşmek Nesneyi Kurmak (203220). Istanbul: Ayrıntı.

Van Gelder, S., (2011). Introduction: How Occupy Wall Street changes everything. In: Van Gelder S (ed.) This Changes Everything: Occupy Wall Street and the 99\% Movement. San Francisco, CA: Berrett-Koehler.Accessed from: http://www.yesmagazine.org/pdf/thischangeseverything/introductiontce.pdf, on 17.11.2015. 